5 Severy DM, Matthewson JH, Bechtel C. Controlled automobile rear-end collisions: An investigation of related engineering and medical phenomena. Can Serv Med J 1955; 11:727-37.

6 Yarnell PR, Rossie GV. Minor whiplash head injury with major debilitation. Brain Injury 1988;3:255-8.

7 Khurana RK, Nirankari VS. Bilateral sympathetic dysfunction in post-traumatic headaches. Headache 1986;26:183-8.

8 Bartschi-Rochaix $W$. Headaches of cervical origin. In: Vinken PJ, Bruyn GW, eds. Handorigin. In: Vinken PJ, Bruyn GW, eds. Hand-

9 Foley-Nolan D, Kinnirons P, O'Connor P Coughlan RJC. Post whiplash dystonia wel
Coley-Nolan D, Kinnirons P, O'Connor P controlled by TENS. J Trauma (In Press).

\section{Pearce replies:}

I am grateful for the interest and comments of Drs Foley Nolan and O'Connor on this contentious topic. They raise several points: 1) Hohl's series can not be taken as a control group since they were based on a "private orthopaedist's" practice and the assessment was after settlement of compensation claims.
The difference from Gotten's series (45\% versus $12 \%$ symptomatic two years after compensation) in itself suggests variation in patient material, motivation for recovery, or a different approach by doctor to complainant. Dissatisfaction with the outcome in court may be germane.

2) Nolan and O'Connor repeatedly refer to soft tissue damage and then confusedly say "The cervical lesion that causes local persistent symptoms may not be a soft tissue injury at all, notwithstanding the fact that soft tissue injuries occur at the same time." Res ipse loquitur!

3) Because of a force detected experimentally over the frontal cortex with rear end impacts (which comprise only 40 to $50 \%$ of whiplash injuries) they place emphasis on change in mood and cognitive ability; then separately, on "rare cases of bilateral sympathetic dysfunction". Alas, there is no evidence of even the most subtle structural lesions in either situation in most whiplash injuries.
4) They rightly look to MRI to demonstrate what type of soft tissue injury occurs and whether they are prognostically important. In my paper I referred to 19 patients with moderate or severe persisting symptoms examined by MRI; the results were normal in every case.

Like many others Nolan and O'Connor indulge in endless speculation, trying (so far in vain) to show subtle organic mechanisms to explain symptoms which are otherwise inexplicable in organic terms. It is mystifying that they choose to ignore one such mechanism: the fact that some people from all classes consciously seek to enhance the financial and other rewards deriving from injury. A few trips, incognito, on the back of a Dublin bus or in cafés frequented by the underoccupied might afford them a hearing of what makes certain folks tick-and how.

JMS PEARCE

Department of Neurology, Hull Royal Infirmary,
Hull HU3 $2 J Z$

\section{BOOK REVIEWS}

Atlas of the Cerebral Sulci. By M ONO, KUBIK, C D ABERNATHEY (Pp 218 illustrated; Price: DM 298.00). Stuttgart: Georg Thieme Verlag, 1990. ISBN 3-13-732101-8

There have been major advances in the knowledge of the anatomy of the brain over the past 40 years but this book is the firs comprehensive study covering all aspects of the cerebral sulci for many years. This work by two neurosurgeons and a Professor of Anatomy, deals in great detail with the primary, secondary and tertiary sulcal divisions. The book is beautifully produced and illustrated. In his foreword, Dr Yasargil rightly draws attention to the increasing precision of surgical techniques and the necessity for improving our knowledge of micro-anatomy. He concludes that the firs step is the necessity of understanding the anatomy of the cortical sulci towards describing and categorising the highly varied structural patterns of the cortical surface.

Although dealing mainly with the descriptions of the cortical sulci, considerable attention is given to the analysis of the variations of the secondary and tertiary sulci. The authors give many of their results in percentage figures but do not state the number of specimens studied. Similarly, the marked variation of the measurements of the sulcal and intersulcal distances makes one question their value in relating them to micro-surgical techniques.

This book will be of value to Neurosurgeons and to Students but one feels that a greater understanding of these structures would have been achieved if there had been some reference to the subcortical anatomy and function.

M GOODING

Trigeminal Neuralgia. Edited by $R \quad L$ ROVIT, R MURALI, and P J JANNETTA. (Pp 288;

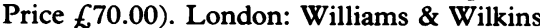
Ltd, 1990. ISBN 0-683-07393-1

This is an excellent book giving a compre- hensive account of the always distressing and consistently interesting problem of trigeminal neuralgia. The meat of the book is in the middle chapters. These give detailed descriptions of the more commonly used methods of medical and surgical treatment of the condition. Peripheral nerve injections, avulsion, radio-frequency coagulation, percutaneous microcompression, glycerol rhizotomy and microvascular decompressive techniques are covered and the advantage and disadvantages of each are clearly outlined. The recently appointed neurosurgeon should be able to undertake the various techniques with minimal hazard, and neurosurgeons in training will find it invaluable.

Perhaps the most interesting chapters for the more experienced neurosurgeons come at the beginning and the end of the book. The analysis of the literature by Dr Sweet discusses in some depth possible mechanisms of causation and pathophysiology. The chapter on Historical perspectives by $\mathrm{Dr}$ Wilkins is perhaps the most interesting. It discusses the range and nature of attempts at treatment often quite bizarre, undertaken in the past and will make salutary reading for anyone who considers that trigeminal neuralgia and its treatment is no longer controversial. The book is well produced and the illustrations are clear and usually relevant, but at $£ 70.00$ the price is on the expensive side for the surgeon in training, but it will find a welcome place in most neurosurgical libraries.

DAVID G HARDY

\section{SHORT NOTICES}

Principles and Practice of Surgery 2nd ed. Edited by A P M FORREST, D C CARTER, I B MACLEOD. (Pp 729 illustrated; Price: £24.95.) Edinburgh: Churchill Livingstone, 1990. ISBN 443039097

If a general surgical textbook is not the normal reading fodder of a neurologist, this beautifully produced illustrated paperback volume will be ideal for their medical children. Stemming from the distinguished Edinburgh School of Surgery and now in its second edition, the contributors hail mainly from Edinburgh and cover both general and specialised surgical topics at a level suitable for undergraduates.

A DSM-III-R Casebook of Treatment Selection. By S PERRY, A FRANCES, J CLARKIN. (Pp 395; Price: \$83.50.) New York: Raven Press, 1990. ISBN 0876305729.

This renewed issue lists 53 detailed case histories followed by discussion of the clinical process and evaluations of a variety of treatments available. The authors discuss their choices and then elaborate the outcome of treatment in each case. The widening spectrum of available treatments for psychiatric disorders makes this particular type of presentation especially helpful. Short lists of suggestive reading enhance the production.

Handbook of Ocular Drug Therapy and Ocular Side Effects of Systemic Drugs. By D PAVAN-LANGSTON AND EC DUNKel. (Pp 464; Price: Not stated). Boston, Mass: Little, Brown \& Co, 1990. ISBN 0316695459.

Peripheral Neuropathy in Childhood (The International Review of Child Neurology). By RA OUVRIER, JG MCLEOD AND JD POLLARD. (Pp 242; Price: \$101.00). New York, Raven Press, 1990. ISBN 0-88167690-X.

An up to date short survey on neuropathy in childhood which overlaps considerably with syndromes of the adult. It is well produced and illustrated, replete with modern references. A very useful concise handbook for paediatric and adult neurologists.

Neurotransmitter and Dementia Journal of Neural Transmission. (1990) Supplement 30 . Edited by $\mathrm{C}$ G GOTTFRIES AND $s$ NAKAMURA (Pp 81; Price: DM 70, Subscribers DM 63) 1990. Wien, Springer-Verlag. ISBN 3211821902 